\title{
Alternative low-cost precipitation kit for assessing irrigation systems
}

\section{Kit de precipitação alternativo de baixo custo para avaliação de sistemas de irrigação}

\author{
Roberto Filgueiras ${ }^{1 *}$; Fernando França da Cunha ${ }^{2}$; Luan Peroni Venancio ${ }^{1}$; \\ Daniel Althoff ${ }^{3}$; Robson Argolo do Santos ${ }^{3}$; Jannaylton Éverton Oliveira Santos ${ }^{1}$; \\ Carlos Augusto Brasileiro de Alencar ${ }^{2}$
}

Highlights:

A precipitation kit (GESAI Kit) was developed for evaluation of irrigated systems.

The GESAI kit costs 4.3 times less than the existing trademark.

Statistical differences were not observed between the trademark and the GESAI kit.

The GESAI kit is more accessible for smallholders to evaluate their irrigated systems.

\begin{abstract}
Irrigation systems must be assessed periodically to verify equipment quality and the need for adjustments. For this, precipitation test kits are necessary. However, commercially available kits have as their main disadvantage the high cost. Therefore, this study aimed to develop an alternative low-cost precipitation kit and verify its efficiency compared to an available commercial brand. The validation test was carried out at the Laboratory of Hydraulics of the Federal University of Viçosa (UFV) using a conventional sprinkler system organized in a quadrangular arrangement. Water collections were carried out within two hours using a grid of plastic collectors spaced at $3 \times 3 \mathrm{~m}$ and installed at $0.7 \mathrm{~m}$ above the ground. The coefficient of determination $\left(\mathrm{R}^{2}\right)$, uniformity coefficients, application efficiency, and thematic maps of the spatial variability of the applied irrigation depth were compared between kits and used for the validation of measurements. The results showed a high agreement between the developed (GESAI) and a commercial kit (Trademark) $\left(\mathrm{R}^{2}=0.9849\right)$, and a high spatial agreement between the collected water depths. Therefore, the GESAI kit is a low-cost alternative for the assessment of irrigation systems.
\end{abstract}

Key words: Irrigation efficiency. GESAI kit. Rain gauge. Distribution uniformity.

\section{Resumo}

Os sistemas de irrigação devem ser avaliados periodicamente para a verificação da qualidade do equipamento e a necessidade de ajustes. Para isso, kits de ensaios de precipitação são necessários, entretanto, os kits comercialmente disponíveis apresentam como principal desvantagem o elevado custo. Assim, o presente trabalho teve como objetivo elaborar um kit de precipitação alternativo de baixo custo e averiguar a sua eficiência frente a marca comercial disponível. O ensaio de validação

\footnotetext{
${ }^{1}$ Drs., Universidade Federal de Viçosa, Departamento de Engenharia Agrícola, DEA/UFV, Viçosa, MG, Brasil. E-mail: roberto.f.filgueiras@ufv.br; lpagronomo1990@gmail.com; jannaylton@gmail.com

2 Profs., Drs., Departamento de Engenharia Agrícola, DEA/UFV, Viçosa, MG, Brasil. E-mail: fernando.cunha@ufv.br; brasileiro@ ufv.br

3 Discentes de Doutorado, Departamento de Engenharia Agrícola, DEA/UFV, Viçosa, MG, Brasil. E-mail: daniel.althoff@ufv.br; robson.argolo@ufv.br

* Author for correspondence
} 
foi realizado no Laboratório de Hidráulica da Universidade Federal de Viçosa (UFV), utilizando um sistema de aspersão convencional, disposto em um arranjo quadrangular. As coletas de água foram realizadas no período de duas horas, com auxílio de uma malha de coletores plásticos espaçados em 3 x $3 \mathrm{~m}$ e instalados a $0,7 \mathrm{~m}$ acima do solo. Para comparação e validação das medições foram utilizados o coeficiente de determinação $\left(\mathrm{R}^{2}\right)$, coeficientes de uniformidade, eficiência de aplicação e mapas temáticos da variabilidade espacial da lâmina aplicada entre os kits. Os resultados mostraram que houve elevada concordância entre o kit desenvolvido (GESAI) e o kit comercial (Trademark) $\left(\mathrm{R}^{2}=0,9849\right)$ e uma concordância espacial elevada entre as lâminas coletadas. Portanto, recomenda-se o uso do kit GESAI como uma alternativa de baixo custo para a avaliação de sistemas de irrigação.

Palavras-chave: Eficiência de irrigação. Kit GESAI. Pluviômetro. Uniformidade de distribuição.

Agriculture is the largest consumer of fresh water on the planet, responsible, on average, for $70 \%$ of its all use (Food and Agriculture Organization \& World Water Council [FAO/WWC], 2015). In Brazil, this value reaches $68.4 \%$ (Agência Nacional das Águas [ANA], 2019). In 2050, it is predicted that agriculture will continue to be the largest consumer of water on the planet, accounting for more than half of the withdrawals from rivers, lakes, and aquifers (FAO/WWC, 2015). In addition, the fact that fresh water scarcity is increasingly perceived as a global systemic risk is worrying (Mekonnen \& Hoekstra, 2016). Thus, it is of high relevance that water consumers in agriculture use systems with high irrigation efficiency (Ei) to reduce their water use and, at the same time, increase crop productivity.

Irrigation efficiency can be defined as the amount of water applied by irrigation that is used by plants, being an indicator that comprehensively reflects the efficiency of irrigation projects, water management, and the technology used in irrigation (Wu, Cui, \& Luo, 2019). This efficiency is the product between application (Ea), distribution (Ed), and conduction efficiency (Ec). Thus, application, distribution, and conduction of the irrigation system need to be assessed in situ to estimate Ei. Ec refers to leaks that occur during water conduction from the pumping system to the final discharge, making identification and correction easier. Thus, Ei is given by the product between Ea and Ed.

According to Tarjuelo, Ortega, Montero and Juan (2000), Ea accounts for evaporation and drift losses. Smajstrla and Zazueta (1994) observed that evaporation losses correspond to the evaporation of drops of water fragmented by pressure, while losses due to drift are related to the displacement of drops of water by the wind effect. Therefore, wind speed, solar radiation, relative humidity, air temperature, and system operating pressure influence Ei. Models based on these parameters have been developed to quantify evaporation and drift losses (Beskow, Colombo, Ribeiro, Ferreira, \& Rossi, 2008; Keller \& Bliesner, 1990; Tarjuelo et al., 2000). However, these estimates can lead to errors. The measured Ea is the most correct, as a grid of collectors is installed under the irrigation system to measure the water that reaches the target to be irrigated.

Distribution efficiency is assessed by distribution uniformity (Ud), which consists of a measure of the capacity of an irrigation system to apply the same amount of water to the entire irrigated area (Baum, Dukes, \& Miller, 2005; Mohamed, Peters, Zhu, \& Sarwar, 2019). Ed is an important factor in designing and managing irrigation systems, as it is directly related to crop yield and water use efficiency (Clemmens, 1991; Maroufpoor, Shiri, \& Maroufpoor, 2019; Mohamed et al., 2019). Uniformity of production when water is the only limiting factor is a function of $\mathrm{Ud}$ of the water in the root zone (López-Mata, Tarjuelo, Juan, Ballesteros, \& Domínguez, 2010).

Distribution uniformity of different types of irrigation is influenced by different factors inherent to each system (Ascough \& Kiker, 2002). 
Uniformity of sprinkler systems depends not only on the characteristics of this system (e.g., flow, working pressure, spacing, and nozzle diameter) but also on climate conditions and, especially, wind speed and direction (Keller \& Bliesner, 1990; Mantovani, Bernardo, \& Palaretti, 2009). Its estimate is frequently assessed based on uniformity coefficients, such as Christiansen's uniformity coefficient (CUC) (Christiansen, 1942), from irrigation depths collected by a network of standardized measuring devices evenly distributed in the irrigated area.

Measuring Ei throughEa andEd is still a challenge for many producers, especially those of small and medium-sized rural properties and even for some institutions in the field of agricultural sciences. It is due to the high cost that the precipitation kit, necessary for the assessment, has on the market. Thus, its acquisition by users with less economic power is often not viable. On the other hand, this limitation can be circumvented by building an alternative kit, with the same functions as those of a commercial kit, but with a lower acquisition cost, as it will be shown in this manuscript.

Thus, based on the importance of assessing irrigation efficiency, the high cost of precipitation kits available on the market, and to ensure that the proposed kit could measure the irrigation depths with the same reliability as the measurements obtained with meters already on the market, this study aimed to elaborate an alternative low-cost precipitation kit and verify its efficiency compared to an available commercial brand.

This study was conducted at the Laboratory of Hydraulics of the Department of Agricultural Engineering (DEA) of the Federal University of
Viçosa (UFV), located in the municipality of Viçosa, MG, Brazil, whose geographical coordinates are $20^{\circ} 46^{\prime} 20^{\prime \prime} \mathrm{S}$ and $42^{\circ} 52^{\prime} 29^{\prime \prime} \mathrm{W}$, DATUM WGS-84, with an altitude of $651 \mathrm{~m}$.

The kit named GESAI will serve to assist in the assessment of irrigation systems with a more affordable financial cost. It received this name because it was developed by members of the Grupo de Estudos e Soluções para Agricultura Irrigada (GESAI, Group for Studies and Solutions for Irrigated Agriculture), belonging to DEA-UFV.

The GESAI kit (Figure 1) consists of rods, collectors, graduated cylinders, and packaging (optional). Rods (Figure 1A) are made of iron rebar with $5 \mathrm{~mm}$ thick, $70 \mathrm{~cm}$ long, and an average mass of $101.75 \mathrm{~g}$. One end of the rod was beveled to facilitate its penetration into the soil. Collectors (Figure 1B) have white color, a height of 101.91 $( \pm 0.20) \mathrm{mm}$, upper and lower radii of $35.76( \pm 0.30)$ and $28.00( \pm 0.10) \mathrm{mm}$, respectively, resulting in a volume of $327.09( \pm 2.88) \mathrm{cm}^{3}$. The average mass of each collector plus an adapter for the rod is $18.20 \mathrm{~g}$. An instant adhesive was used to attach the adapter to the lower outer part of the collector. A nylon tube with an internal diameter of $6 \mathrm{~mm}$, an external diameter of $8 \mathrm{~mm}$, and a length of $20 \mathrm{~mm}$ was used to make the adapter, as shown in Figure 1A. The graduated cylinder (Figure 1C) is made of plastic and graduated in milliliters $(\mathrm{mL})$, with a maximum volume of $50 \mathrm{~mL}$. The package (Figure 1D) has a size of $80 \mathrm{~cm}$, a diameter of $200 \mathrm{~mm}$, a mass of $1,680 \mathrm{~g}$, and consists of polyvinyl chloride (PVC), with the capacity to store one graduated cylinder and 50 rod-collector sets. The GESAI kit has a total mass of 7,700 $\mathrm{g}$ when complete (50 stem-collector sets). 

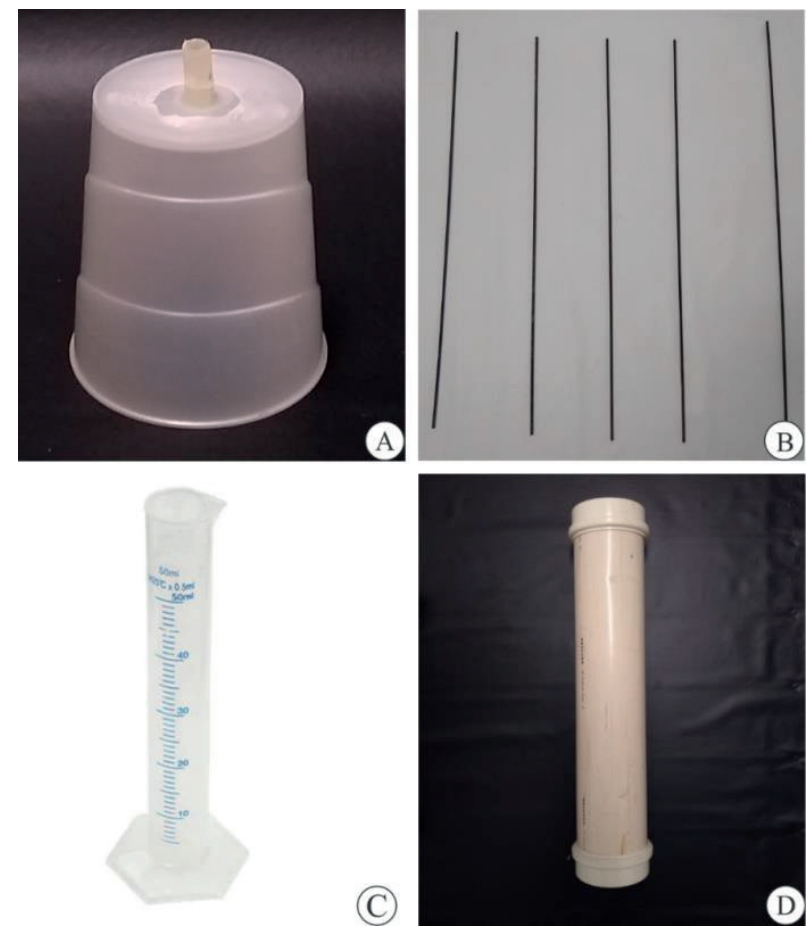

Figure 1. GESAI kit. A) Collectors; B) rods; C) graduated cylinder; and d) packaging.

The commercial precipitation kit, called in this study as a Trademark precipitation kit, is dominant on the market and was used to validate the GESAI kit. For this, both precipitation kits were installed in the field under a conventional sprinkler irrigation system (Figures 2 and 3). Nine field tests with a duration of 120 min each were carried out under different climate conditions from September 24 to September 25, 2018.
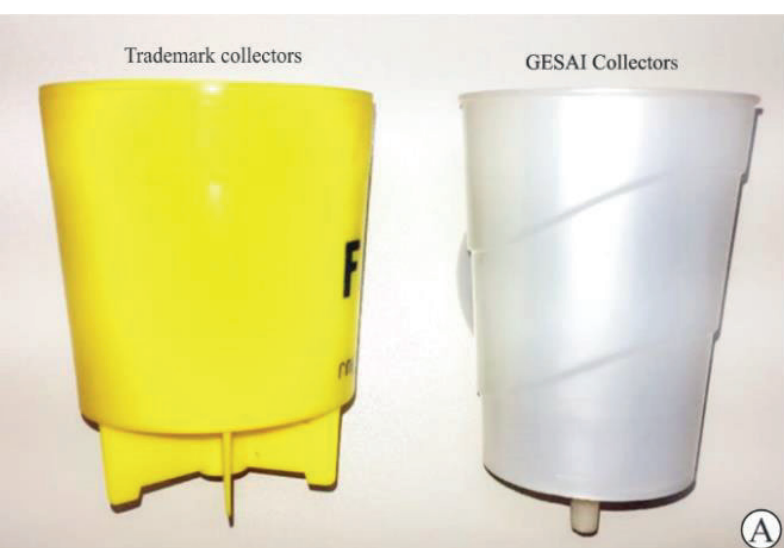

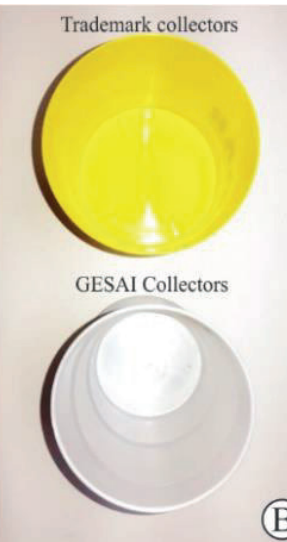

(B)

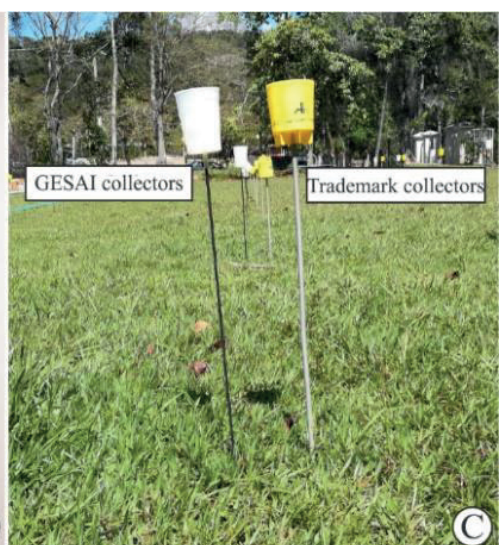

Figure 2. Details of GESAI and Trademark kits for assessment of irrigated systems. 


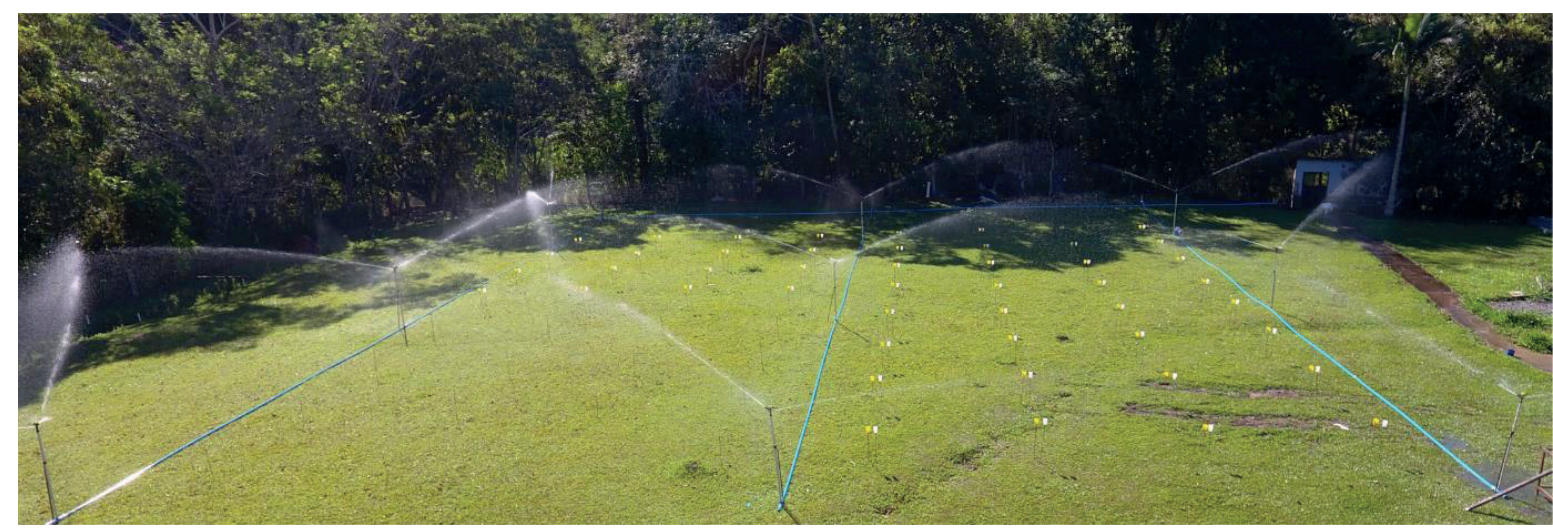

Figure 3. Arrangement of collectors in the experimental area.

The irrigation system had three lateral lines spaced at $12 \mathrm{~m}$. Each lateral line had three sprinklers, spaced at $12 \mathrm{~m}$ (Figure 3). These nine sprinklers were manufactured by FABRIMAR, model MIDI, with two nozzles with a diameter of 3.6 and $2.6 \mathrm{~mm}$. Sprinklers were supported by a $1.7-\mathrm{m}$ rise pipe, with an average working pressure of $250 \mathrm{kPa}$, generating a flow of $1.18 \mathrm{~m}^{3} \mathrm{~h}^{-1}$ and a wet diameter of $25 \mathrm{~m}$. Sprinklers operated at an angle of $360^{\circ}$ and an average turning time of $39 \mathrm{~s}$.

The area between four sprinklers, working simultaneously, was subdivided into rectangular subareas with dimensions of $9 \mathrm{~m}^{2}$, following the Brazilian standard ABNT-NBR 14244 (Associação Brasileira de Normas Técnicas [ABNT], 1998). Collectors (GESAI and Trademark) were installed in the center of each sub-area (Figure 3), being equidistant at $3 \mathrm{~m}$, which resulted in 16 collectors in each kit. Collectors were suspended by a rod at $70 \mathrm{~cm}$ high from the soil surface, following the methodology proposed by Merriam and Keller (1978).

The data on average air temperature, relative humidity, solar radiation, and wind speed were collected throughout the testing period using an automatic weather station. The time spent with water application by the sprinklers in each irrigated quadrant $\left(90^{\circ}\right)$ was measured for each $360^{\circ}$ rotation, with three replications. Also, nozzle pressures and flows of all sprinklers were measured, with three replications, at the beginning and end of each test. Pressures were obtained using a glycerin manometer, and flow was obtained by the direct method.

Water depths were measured in each collector at the end of each test using a graduated cylinder. The collected volumes were converted into water depths $(\mathrm{mm})$ by dividing the collected volume (L) by the collector area $\left(\mathrm{m}^{2}\right)$. Water evaporation was also quantified in both collectors from a known initial water volume, which was read at the end of the tests, and the difference corresponded to the evaporation. This difference was added to the reading carried out in the tested collectors.

Linear regression was adjusted with the data of water depths collected by the Trademark and GESAI kits. Coefficients of position $(a)$, slope $(b)$, and determination $\left(\mathrm{R}^{2}\right)$ were considered in the analysis. Thus, the GESAI kit will only be recommended if the regression coefficient $a$ approaches zero and coefficients $b$ and determination approach the unit. Precision was given by $\mathrm{R}^{2}$, as it indicates the degree to which the regression explains the total sum of squares.

Subsequently, an interpolation by the inverse distance weighted (IDW) $($ weight $=2)$ was performed using the collected water depths from each collector of both kits to observe their spatial distribution in the area. The difference between thematic maps, 
generated from the water depths of each kit, was also considered. Thus, nine thematic maps were generated for the water depth collected by each kit plus the other nine maps referring to the differences between kits (Trademark kit - GESAI kit).

Water application uniformity was calculated by Christiansen's $\left(\mathrm{U}_{\mathrm{C}}\right)$, distribution $\left(\mathrm{U}_{\mathrm{D}}\right)$, statistical

$$
\begin{aligned}
& \mathrm{U}_{\mathrm{C}}=100\left[1-\frac{\sum_{\mathrm{i}=1}^{\mathrm{n}}\left|\mathrm{X}_{\mathrm{i}}-\overline{\mathrm{X}}\right|}{\mathrm{n} \overline{\mathrm{X}}}\right] \\
& \mathrm{U}_{\mathrm{D}}=100 \frac{\mathrm{X}_{25 \%}}{\overline{\mathrm{X}}} \\
& \mathrm{U}_{\mathrm{S}}=100\left[1-\frac{\mathrm{S}}{\overline{\mathrm{X}}}\right] \\
& \mathrm{U}_{\mathrm{H}}=100\left\{1-\sqrt{\frac{2}{\pi}}\left(\frac{\mathrm{S}}{\overline{\mathrm{X}}}\right)\right\} \\
& \mathrm{U}_{\mathrm{HSPA}}=100\left(1-1.27 \frac{\mathrm{S}}{\overline{\mathrm{X}}}\right)
\end{aligned}
$$

$\left(\mathrm{U}_{\mathrm{S}}\right)$, Hart's $\left(\mathrm{U}_{\mathrm{H}}\right)$, and HSPA $\left(\mathrm{U}_{\mathrm{HSPA}}\right)$ uniformity coefficients using Equations (1), (2), (3), (4), and (5), respectively. The uniformity data were subjected to the F-test at a 5\% probability to compare the Trademark and GESAI methods. The experimental package Designs from the software $\mathrm{R}$ was used to perform the statistical analyses. where $\mathrm{U}_{\mathrm{C}}$ is Christiansen's uniformity coefficient (\%) (Christiansen, 1942), $\mathrm{X}_{\mathrm{i}}$ is the precipitation observed in the collectors (mm), is the mean of precipitations $(\mathrm{mm}), \mathrm{n}$ is the number of collectors, $\mathrm{U}_{\mathrm{D}}$ is the distribution uniformity coefficient (\%) (Criddle, 1956), $\mathrm{X}_{25 \%}$ is the mean of $25 \%$ of the total collectors with the lowest precipitations $(\mathrm{mm}), \mathrm{U}_{\mathrm{S}}$ is the statistical uniformity coefficient (\%) (Wilcox

\& Swailes, 1947), S is the standard deviation of the precipitation data $(\mathrm{mm}), \mathrm{U}_{\mathrm{H}}$ is the Hart's uniformity coefficient (\%) (Hart, 1961), and $\mathrm{U}_{\mathrm{HSPA}}$ is the HSPA uniformity coefficient (\%) (Hart, 1961).

The data obtained from $\mathrm{U}_{\mathrm{C}}, \mathrm{U}_{\mathrm{D}}$, and $\mathrm{U}_{\mathrm{S}}$ were interpreted following the proposal of Mantovani (2001), as shown in Table 1.

\section{Table 1}

Classification of $U_{C}, U_{D}$, and $U_{S}$ values for sprinkler systems, according to Mantovani (2001)

\begin{tabular}{lccc}
\hline \multicolumn{1}{c}{ Classification } & $\mathrm{U}_{\mathrm{C}}(\%)$ & $\mathrm{U}_{\mathrm{D}}(\%)$ & $\mathrm{U}_{\mathrm{S}}(\%)$ \\
\hline Excellent & $>90$ & $>84$ & $90-100$ \\
Good & $80-90$ & $68-84$ & $80-90$ \\
Moderate & $70-80$ & $52-68$ & $70-80$ \\
Poor & $60-70$ & $36-52$ & $60-70$ \\
Unacceptable & $\leq 60$ & $\leq 36$ & $<60$ \\
\hline
\end{tabular}

The calculation of the evaporation and drift loss (EDL) considered the arithmetic mean of the water depth applied by sprinklers and that measured in the
Trademark and GESAI collectors, being calculated using Equation (6).

$$
\mathrm{EDL}=\frac{\mathrm{W}_{\text {applied }}-\mathrm{W}_{\text {collected }}}{\mathrm{W}_{\text {applied }}}
$$


in which EDL is the evaporation and drag loss (\%), $\mathrm{W}_{\text {applied }}$ is the applied water depth ( $\left.\mathrm{mm}\right)$, and $\mathrm{W}_{\text {collected }}$ is the collected water depth ( $\mathrm{mm})$.

However, data processing was based on application efficiency (Ea). In this case, the EDL values were subtracted from 100 .
Besides being measured, Ea was estimated by different models as a function of weather conditions during the tests. The mathematical models used in the present study were proposed by Keller and Bliesner (1990), Tarjuelo et al. (2000), and Beskow et al. (2008), as shown in Table 2.

Table 2

Equations for modeling the application efficiency used in this study

\begin{tabular}{|c|c|}
\hline Methodology & Empirical equation \\
\hline Keller \& Bliesner (1990) & $\begin{array}{c}\mathrm{Ea}=100\left[0.976+0.005 \mathrm{ET}_{0}-0.0001 \mathrm{ET}_{0}^{2}+0.0012 \mathrm{u}_{2}\right)-\mathrm{CI}\left(0.00043 \mathrm{ET}_{0}+0.00018\right. \\
\left.\left.\mathrm{u}_{2}+0.000016 \mathrm{ET}_{0} \mathrm{u}_{2}\right)\right], \text { where CI is a function of the baffle plate. }\end{array}$ \\
\hline Tarjuelo et al. (2000) & $\mathrm{Ea}=100-\left[0.007 \mathrm{WP}+7.38\left(\mathrm{e}_{\mathrm{s}}-\mathrm{e}_{\mathrm{a}}\right)^{0.5}+0.844 \mathrm{u}_{2}\right]$ \\
\hline Beskow et al. (2008) & $\mathrm{Ea}=100-\left[-0.0304 \mathrm{WP}+13.2976\left(\mathrm{e}_{\mathrm{s}}-\mathrm{e}_{\mathrm{a}}\right)^{0.5}+5.485 \mathrm{u}_{2}\right]$ \\
\hline
\end{tabular}

$\mathrm{Ea}=$ application efficiency $(\%) ;\left(\mathrm{e}_{\mathrm{s}}-\mathrm{e}_{\mathrm{a}}\right)=$ vapor pressure deficit $(\mathrm{kPa}) ; \mathrm{WP}=$ sprinkler working pressure $(\mathrm{kPa}) ; \mathrm{u}_{2}=\mathrm{average}$ wind speed $\left(\mathrm{m} \mathrm{s}^{-1}\right) ; \mathrm{T}=$ air temperature $\left({ }^{\circ} \mathrm{C}\right)$.

Vapor pressure deficit $(\Delta \mathrm{e})$ and vapor saturation pressure $\left(\mathrm{e}_{\mathrm{s}}\right)$ were obtained by Equations (7) and (8).

$$
\begin{aligned}
& \Delta \mathrm{e}=\mathrm{es}(\mathrm{T})-[\mathrm{RH} \times \mathrm{es}(\mathrm{T})] \\
& \text { es }=0.61078 \exp \left(\frac{17.266 \times \mathrm{T}}{\mathrm{T}+237.3}\right)
\end{aligned}
$$

where $\Delta \mathrm{e}$ is the vapor pressure deficit $(\mathrm{kPa})$, es is the saturation vapor pressure $(\mathrm{kPa}), \mathrm{T}$ is the mean temperature $\left({ }^{\circ} \mathrm{C}\right)$, and $\mathrm{RH}$ is the relative air humidity (\%).

$$
\begin{aligned}
& \mathrm{RMSE}=\sqrt{\frac{1}{\mathrm{n}} \sum\left(\mathrm{P}_{\mathrm{i}}-\mathrm{O}_{\mathrm{i}}\right)^{2}} \\
& \mathrm{MBE}=\frac{1}{\mathrm{n}} \sum\left|\mathrm{P}_{\mathrm{i}}-\mathrm{O}_{\mathrm{i}}\right|
\end{aligned}
$$

in which RMSE is the root-mean-square error (\%), MBE is the mean bias error (\%), $\mathrm{P}_{\mathrm{i}}$ is the value measured using the GESAI kit or predicted by the model $(\%), \mathrm{O}_{\mathrm{i}}$ is the value measured using the Trademark kit (\%), and $\mathrm{n}$ is the number of data pairs.

Budgets were made in the retail market to measure the cost of purchasing kits to assess the
The Ea measured using the GESAI kit and estimated by different models were compared to the Ea measured by the Trademark kit. For this, the statistical indicators root-mean-square error (RMSE) and mean bias error (MBE) were used, according to Equations (9) and (10).

irrigation systems. Each item of the GESAI kit, which will be installed by the user, was budgeted separately at three supplier companies. The average value of the GESAI considered the prices of 150 rods, 150 collectors, three graduated cylinders, one package, $3.5 \mathrm{~m}$ of adapter tube, and $60 \mathrm{~g}$ of instant adhesive. The items that compose the Trademark kit 
are marketed together, consisting of 150 collectors, 150 rods, three graduated cylinders, and packaging. Similarly, three budgets were requested from three supplier companies, but the freight cost was not considered to obtain the average value of the Trademark kit. These budgets were made in the period between November 16 and 26, 2018, when the US dollar was R\$3.79.

Table 3 shows the hydraulic and meteorological data related to the assessments. The values of working pressure (WP) and flow rate remained approximately constant for the nine assessments, except for assessments 6 and 9, which showed considerably lower WP values. The flow rates obtained from the tests were similar to those specified in the manufacturer's catalog. The hourly reference evapotranspiration was more intense for assessments 7, 8, and $9\left(\right.$ ETo $\left.=0.67 \mathrm{~mm} \mathrm{~h}^{-1}\right)$, when the relative air humidity $(\mathrm{RH})$ was low and vapor pressure deficit values $(\Delta \mathrm{e})$ and wind speed at $2 \mathrm{~m}$ high $\left(\mathrm{u}_{2}\right)$ were relatively high.

\section{Table 3}

Hydraulic and meteorological data obtained during the assessments

\begin{tabular}{|c|c|c|c|c|c|c|c|c|c|}
\hline \multirow{2}{*}{ Parameter } & \multicolumn{9}{|c|}{ Assessment } \\
\hline & 1 & 2 & 3 & 4 & 5 & 6 & 7 & 8 & 9 \\
\hline Flow rate $\left(\mathrm{m}^{3} \mathrm{~h}^{-1}\right)$ & 1.205 & 1.211 & 1.216 & 1.200 & 1.205 & 1.203 & 1.200 & 1.205 & 1.203 \\
\hline $\mathrm{WP}(\mathrm{kPa})$ & 260.7 & 263.1 & 265.3 & 258.3 & 260.5 & 220.3 & 258.3 & 260.5 & 223.2 \\
\hline \multirow[t]{2}{*}{$\Delta \mathrm{TT}(\%)$} & 13.43 & 13.99 & 14.59 & 10.77 & 6.72 & 9.74 & 15.00 & 14.49 & 18.20 \\
\hline & \multicolumn{9}{|c|}{ Meteorological data } \\
\hline Temperature $\left({ }^{\circ} \mathrm{C}\right)$ & & 28.00 & & & 21.08 & & & 26.10 & \\
\hline RH (\%) & & 50.00 & & & 75.25 & & & 55.75 & \\
\hline $\mathrm{u}_{2}\left(\mathrm{~m} \mathrm{~s}^{-1}\right)$ & & 1.09 & & & 1.87 & & & 1.57 & \\
\hline$\Delta \mathrm{e}(\mathrm{kPa})$ & & 2.26 & & & 1.14 & & & 2.00 & \\
\hline ETo $\left(\mathrm{mm} \mathrm{h}^{-1}\right)$ & & 0.47 & & & 0.21 & & & 0.67 & \\
\hline
\end{tabular}

$\mathrm{WP}=$ working pressure; $\Delta \mathrm{TT}=$ variation in turn time per quadrant; $\mathrm{RH}=$ relative humidity; $\mathrm{u}_{2}=$ wind speed at $2 \mathrm{~m}$ from the soil; $\Delta \mathrm{e}=$ vapor pressure deficit; ETo $=$ reference evapotranspiration.

According to Dukes (2006), $\mathrm{u}_{2}$ values lower than $1.7 \mathrm{~m} \mathrm{~s}^{-1}$ are classified as low. Thus, $\mathrm{u}_{2}$ values were low in tests 1, 2, 3, 7, 8, and 9 and high in tests 4, 5, and 6 (Table 3). Low $\mathrm{u}_{2}$ values are essential for the quality of precipitation tests, especially in sprinkler systems, in which this meteorological variable has a major impact on the application and distribution of water (Faria et al., 2016). According to ASAE (American Society of Agricultural Engineers [ASAE], 2001), the accuracy of this test procedure for the assessment of a linear system and center pivot decreases when wind speed exceeds $1 \mathrm{~m} \mathrm{~s}^{-1}$. However, this test may not be a valid measure of uniformity or performance of the emitters if wind speed exceeds $5 \mathrm{~m} \mathrm{~s}^{-1}$.

The results for the assessed commercial kit and the GESAI prototype were similar for all the calculated distribution coefficients, with no statistical difference between them (Table 4). Coefficient values ranged from 63.56 to $92.33 \%$, with the highest values found for $\mathrm{U}_{\mathrm{C}}, \mathrm{U}_{\mathrm{H}}, \mathrm{U}_{\mathrm{S}}, \mathrm{U}_{\mathrm{D}}$, and $\mathrm{U}_{\mathrm{HSPA}}$, in that order.

Table 4 shows that the system has excellent $U_{C}$ values, according to the classification proposed by Mantovani (2001), while $U_{D}$ and $U_{S}$ were lower 
than $70 \%$, indicating that the system has moderate values. The $U_{D}$ values will always be lower than the $U_{C}$ values due to the nature of equations, as the former uses the first $25 \%$ of the lowest values of the average water depth. Moreover, $\mathrm{U}_{\mathrm{H}}$ values will always be higher than the $\mathrm{U}_{\mathrm{S}}$ values, which, in turn, will be higher than the $\mathrm{U}_{\text {HSPA }}$ values. The distance between $U_{H}$ and $U_{C}$ values indicates that water depths may not follow a normal distribution. $\mathrm{A}_{\mathrm{S}}$ lower than $75 \%$ may indicate a marked standard deviation in the collected water depths.

Table 4

Distribution coefficients for GESAI and commercial collectors

\begin{tabular}{lccccc}
\hline \multirow{2}{*}{ Parameter } & \multicolumn{5}{c}{ Distribution coefficients } \\
\cline { 2 - 6 } & $\mathrm{U}_{\mathrm{C}}(\%)$ & $\mathrm{U}_{\mathrm{D}}(\%)$ & $\mathrm{U}_{\mathrm{S}}(\%)$ & $\mathrm{U}_{\mathrm{H}}(\%)$ & $\mathrm{U}_{\mathrm{HSPA}}(\%)$ \\
\hline Trademark & 92.33 & 68.83 & 71.42 & 77.58 & 63.71 \\
GESAI & 92.32 & 68.79 & 71.31 & 77.77 & 63.56 \\
F-test & $0.94^{\mathrm{ns}}$ & $0.87^{\mathrm{ns}}$ & $0.84^{\mathrm{ns}}$ & $0.72^{\mathrm{ns}}$ & $0.84^{\mathrm{ns}}$ \\
\hline
\end{tabular}

$U_{C}=$ Christiansen's uniformity coefficient; $U_{D}=$ distribution uniformity coefficient; $U_{S}=$ statistical uniformity coefficient; $U_{H}=$ Hart's uniformity coefficient; $\mathrm{U}_{\mathrm{HSPA}}=$ HSPA uniformity coefficient; ${ }^{\mathrm{ns}}=$ not significant at a $5 \%$ probability by the Snedecor's F-test.

The $U_{C}$ values considered excellent in this study are directly related to excellent operating conditions of the irrigation system and meteorological conditions. It shows the compatibility of this assessment with those carried out at the business level, as companies carry out their tests under controlled or mild field/laboratory conditions with regard to weather and using systems in optimal operating conditions, generating reliable data (Queiroz, Lima, Botrel, \& Frizzone, 2008).

Assessment results showed excellent agreement, with measurements close to the 1:1 line. Also, the $\mathrm{R}^{2}$ showed that the values of the GESAI kit explained $98.49 \%$ of the variation of the data from the Trademark kit (Figure 4). Thus, the GESAI kit allows the same precision in assessments of uniformity of water distribution as commercial kits, but with a lower acquisition cost. Several studies have sought to develop low-cost irrigation technologies, sensors, and other products, such as soil moisture sensors (Gomes et al., 2017; Ramadan, Oates, Molina-Martinez, \& Ruiz-Canales, 2018), rain gauges (Hoffmann, Schwartengräber, Wessolek, \& Peters, 2016), irrigation controllers (Barkunan, Bhanumathi, \& Sethuram, 2019), air temperature and relative humidity (Mota, Alves, Evangelista, \& Casaroli, 2018), and drip irrigation systems (Deveci, Onkol, Unver, \& Ozturk, 2015; Surendran, Jayakumar, \& Marimuthu, 2016). These new technologies and the kit validated in the present study are essential, especially for producers with low purchasing power. 


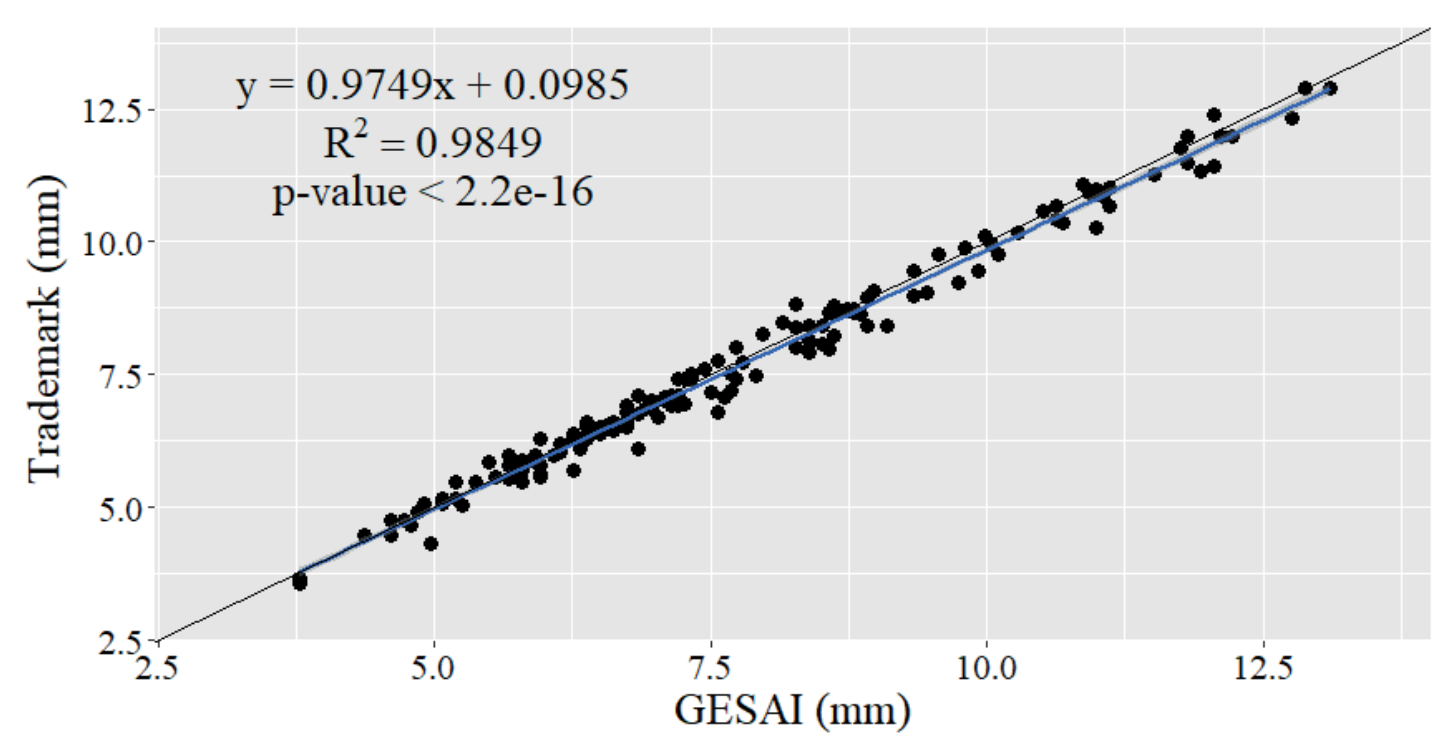

Figure 4. Linear regression between the water depth collected by the Trademark kit and that collected by the GESAI kit. The collected water depths are equivalent to a 60-minute irrigation application.

Figure 5 shows the spatial distribution of water depths collected by kits throughout the performed tests. The GESAI kit presented a spatial pattern similar to that of the Trademark kit in all nine tests. The difference in the patterns between both kits is only noticeable when analyzing the images of the difference between them in the nine tests. The difference images were created precisely to show the sites where both kits presented more disparate measures, as a palette was used to maximize the differences, which were not possible to be observed in the analysis of the spatial distribution of the water depth for each kit only. Even using the difference images, the legend values showed that the differences regarding water depths were very small, with an average value between all collected water depths equal to $0.13 \mathrm{~mm}$, which shows the suitability of GESAI collectors when compared with commercial collectors. 

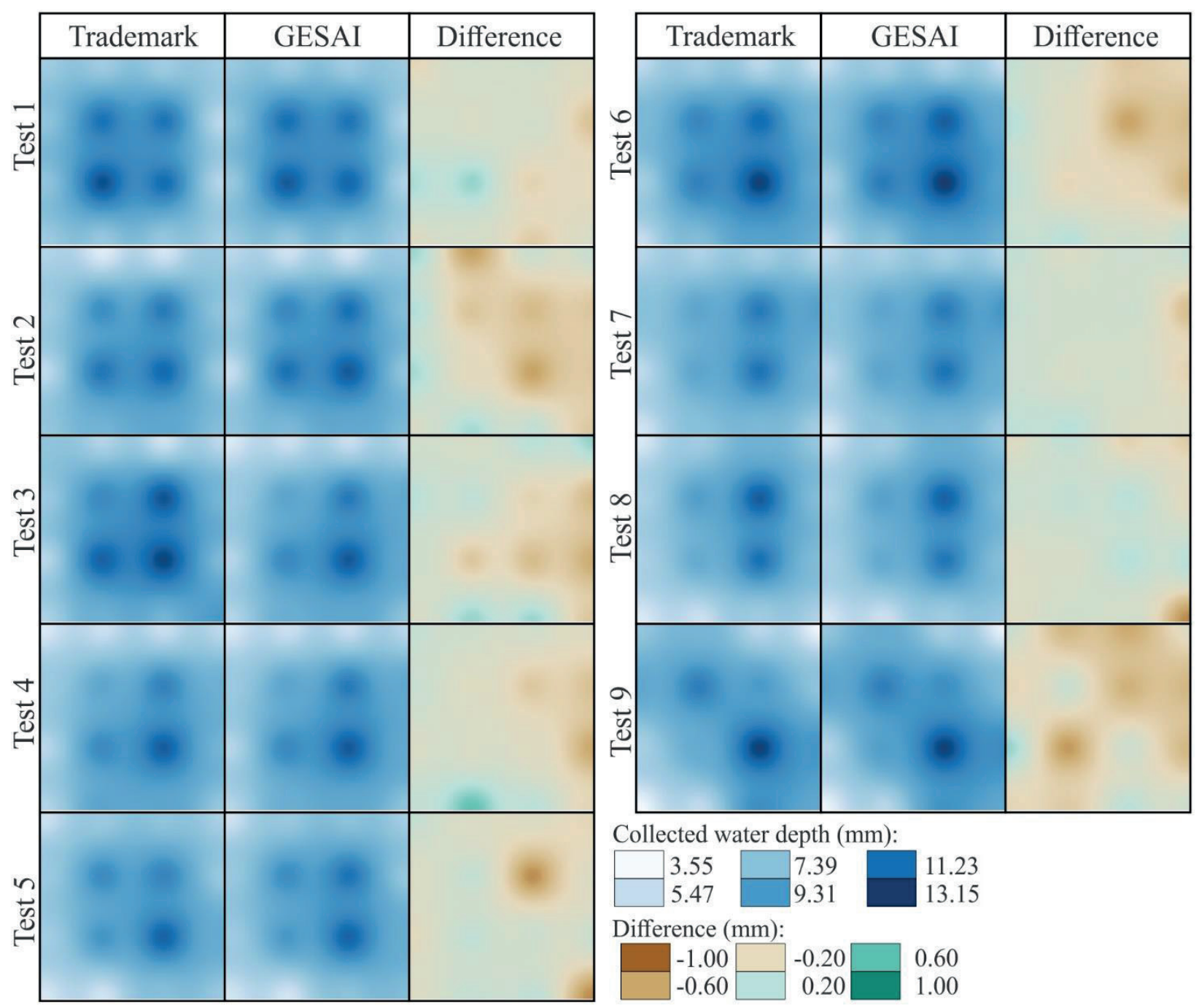

Figure 5. Thematic maps of the spatial distribution of water depths collected by Trademark and GESAI kit and difference between them throughout the nine tests. The collected water depths are equivalent to a 60 -minute irrigation application.

Table 5 shows the application efficiency (Ea) of both kits and that estimated by empirical models. The Ea obtained through the GESAI kit was $1.0 \%$ higher than that of the Trademark kit. In this case, water depths collected in GESAI collectors were higher than the water depths collected in Trademark collectors, as shown in Figures 4 and
5. This small difference can also be attributed to the diameter unevenness of GESAI and Trademark collectors. The standard deviation of the diameter of the Trademark collector was $0.17 \mathrm{~mm}$, which is sufficient to cause a variation in the calculation of the collected water depth in the order of $0.84 \%$. 
Table 5

Application efficiency obtained by Trademark and GESAI kits and estimated by the Beskow et al. (2008), Keller and Bliesner (1990), and Tarjuelo et al. (2000) models and comparison of results (RMSE and MBE) with the efficiency obtained by the Trademark kit

\begin{tabular}{lccc}
\hline Methodology & Mean (\%) & RMSE (\%) & MBE (\%) \\
\hline Trademark & 91.40 & - & - \\
GESAI & 92.40 & 1.22 & 1.00 \\
Beskow & 81.59 & 10.27 & -9.81 \\
Keller and Bliesner & 96.56 & 5.81 & 5.15 \\
Tarjuelo & 87.19 & 5.17 & -4.21 \\
\hline
\end{tabular}

RMSE $=$ root-mean-square error; $\mathrm{MBE}=$ mean bias error.

Even though there was an overestimation of Ea by the GESAI kit, this difference was much lower than the difference observed in the existing models for Ea estimation (Table 5). Regarding the Trademark method, the Keller and Bliesner model (Keller \& Bliesner, 1990) overestimated Ea by $5.15 \%$, and the Beskow (Beskow et al., 2008) and Tarjuelo models (Tarjuelo et al., 2000) underestimated it by 9.81 and $4.21 \%$, respectively. The Keller and Bliesner model has low sensitivity regarding weather variations but had the best performance among the predictive methods. The Beskow model was expected to perform better because it was developed in a region (Lavras-MG) that has more similarity to the meteorological conditions at the location of the present study. The other models were developed in the United States (Keller and Bliesner) and Spain (Tarjuelo). Also, the statistical metrics for the assessed models were superior to the method measured using the GESAI kit, proving its good performance in obtaining Ea.

Irrigation efficiency (Ei) is the product between Ea and Ed, with average values of 84.38 and $85.29 \%$ for the Trademark and GESAI kits, respectively. The GESAI kit overestimated the Ei value by only $1.08 \%$, showing its efficiency compared to the standard kit.

Prices of components of the GESAI kit are shown in Table 6. Collectors had the highest cost, whereas the graduated cylinder presented the lowest cost. However, there are only three graduated cylinders per kit. The average price for the Trademark kit is 4.30 times higher than the value of the GESAI kit proposed in the present study. These costs hinder the acquisition of commercial collectors for most producers, keeping them limited regarding the irrigation system assessment, a routine and essential practice for irrigated agriculture. 
Table 6

Expenses for purchasing the GESAI kit (150 stem-collector sets)

\begin{tabular}{lcc}
\hline Item & Price $(\mathrm{R} \$)$ & Price $(\mathrm{US} \$)^{*}$ \\
\hline Collector & 184.50 & 28.63 \\
Rods & 105.00 & 27.70 \\
Adapter (rods/collector) & 12.00 & 3.17 \\
Adhesive glue (3 units) & 36.00 & 9.50 \\
Graduated cylinder (50 mL) (3 units) & 35.00 & 9.23 \\
Workforce & 100.00 & 26.39 \\
PVC packaging** & 90.00 & 23.75 \\
\hline Subtotal*** & 472.00 & 104.62 \\
\hline Total & 562.50 & 119.14 \\
\hline
\end{tabular}

*Dollar quoted on November 21, 2018, with a value of R\$ 3.79; **optional item; ***total without considering the PVC packaging.

It is important to highlight that, despite the use of the conventional sprinkler system for the assessment and validation of the GESAI kit, this kit can be used for all pressurized irrigation systems (center pivot, linear, self-propelled, drip, and micro-sprinkler).

The tests carried out with the GESAI kit do not differ from tests with collectors of a commercial brand regarding the collected water depth and distribution, application, and irrigation efficiencies.

GESAI collectors are recommended for the assessment of pressurized irrigation systems, as they had excellent operability at a cost much lower than the reference commercial brand.

\section{Acknowledgments}

This study was financed in part by the Coordenação de Aperfeiçoamento de Pessoal de Nível Superior - Brasil (CAPES) - Finance Code 001 and Conselho Nacional de Desenvolvimento Científico e Tecnológico - Brazil (CNPq).

\section{References}

Agência Nacional das Águas. (2019). Manual de usos consutivos da água no Brasil. Recuperado de http://www.snirh.gov.br/portal/snirh/centrais-de- conteudos/central-de-publicacoes/ana_manual_de usos_consuntivos_da_agua_no_brasil.pdf/view

American Society of Agricultural Engineers. (2001). Test procedure for determining the uniformity of water distribution of center pivot and lateral move irrigation machines equipped with spray or sprinkler nozzles. Recuperado de https://www.canr.msu.edu/ uploads/235/67987/ASAE_S436.1.pdf

Ascough, G. W., \& Kiker, G. A. (2002). The effect of irrigation uniformity on irrigation water requirements. Water SA, 28(2), 235-242. doi: $10.4314 /$ wsa.v28i2.4890

Associação Brasileira de Normas Técnicas. (1998). NBR 14244: Equipamentos de irrigação mecanizada -Pivô central e lateral móvel providos de emissores fixos ou rotativos - Determinação da uniformidade de distribuição de água. Rio de Janeiro, 1-11.

Barkunan, S. R., Bhanumathi, V., \& Sethuram, J. (2019). Smart sensor for automatic drip irrigation system for paddy cultivation. Computers \& Electrical Engineering, 73, 180-193. doi: 10.1016/j. compeleceng. 2018.11.013

Baum, M. C., Dukes, M. D., \& Miller, G. L. (2005). Analysis of residential irrigation distribution uniformity. Journal of irrigation and drainage engineering, 131(4), 336-341. doi: 10.1061/ (ASCE)0733-9437 (2005)131:4(336)

Beskow, S., Colombo, A., Ribeiro, M. S., Ferreira, L. S., \& Rossi, R. (2008). Simulação das perdas de água por evaporação e arraste, no aspersor NY-7 (4,6 mm x 4,0 $\mathrm{mm}$ ), em sistemas de aspersão convencional. 
Engenharia Agrícola, 28(3), 427-437. doi: 10.1590/ S0100-69162008000300004

Christiansen, J. E. (1942). Irrigation by sprinkling. (Bulletin, 670). Berkeley: University of California Agricultural Experiment Station.

Clemmens, A. J. (1991). Irrigation uniformity relationships for irrigation system management. Journal of Irrigation and Drainage Engineering, 117(5), 682-699. doi: 10.1061/(ASCE)07339437(1991)117:5(682)

Criddle, W. D. (1956). Method for evaluating irrigation systems. Agriculture Handbook, 82, 2-11.

Deveci, O., Onkol, M., Unver, H. O., \& Ozturk, Z. (2015). Design and development of a low-cost solar powered drip irrigation system using Systems Modeling Language. Journal of Cleaner Production, 102, 529-544. doi: 10.1016/j.jclepro.2015.04.124

Dukes, M. D. (2006). Effect of wind speed and pressure on linear move irrigation system uniformity. Applied Engineering in Agriculture, 22(4), 541-548. doi: $10.13031 / 2013.21222$

Faria, L. C., Beskow, S., Colombo, A., Nörenberg, B. G., Rettore, O., Neto, \& Simões, M. C. (2016). Influence of the wind on water application uniformity of a mechanical lateral move irrigation equipment using rotating plate sprinklers. Ciência Rural, 46(1), 8388. doi: 10.1590/0103-8478cr20141558

Food and Agriculture Organization, \& Word Water Council. (2015). Towards a water and food secure future. Critical perspectives for policy-makers. Roma.

Gomes, F. H. F., Cunha, F. N., Lopes-Filho, L. C., F., Vidal, V. M., Soares, F. A. L., \& Teixeira, M. B. (2017). Calibração de um sensor de umidade do solo de baixo custo. Revista Brasileira de Agricultura Irrigada, 11(4), 1509-1516. doi: 10.7127/rbai. v11n 400605

Hart, W. E. (1961). Overhead irrigation pattern parameters. Agricultural Engineering, 42(7), 354355.

Hoffmann, M., Schwartengräber, R., Wessolek, G., $\&$ Peters, A. (2016). Comparison of simple rain gauge measurements with precision lysimeter data. Atmospheric Research, 174, 12-123. doi: 10.1016/j. atmosres.2016.01.016

Keller, J., \& Bliesner, R. D. (1990). Sprinkle and trickle irrigation. New York, NY: Van Nostrand Reinhold.
López-Mata, E., Tarjuelo, J. M., Juan, J. A. de, Ballesteros, R., \& Domínguez, A. (2010). Effect of irrigation uniformity on the profitability of crops. Agricultural Water Management, 98(1), 19-198. doi: 10.1016/j.agwat.2010.08.006

Mantovani, E. C. (2001). AVALIA: Programa de Avaliação da Irrigação por Aspersão e Localizada. Viçosa, MG: UFV.

Mantovani, E. C., Bernardo, S., \& Palaretti, L. F. (2009). Irrigação princípios e métodos. Viçosa: UFV.

Maroufpoor, S., Shiri, J., \& Maroufpoor, E. (2019). Modeling the sprinkler water distribution uniformity by data-driven methods based on effective variables. Agricultural Water Management, 215, 63-73. doi: 10.1016/j.agwat.2019.01.008

Mekonnen, M. M., \& Hoekstra, A. Y. (2016). Four billion people facing severe water scarcity. Science Advances, 2(2), e1500323. doi: 10.1126/ sciadv. 1500323

Merriam, J. L., \& Keller, J. (1978). Farm irrigation system evaluation: a guide for management. Logan, Utah: Utah State University.

Mohamed, A. Z., Peters, R. T., Zhu, X., \& Sarwar, A. (2019). Adjusting irrigation uniformity coefficients for unimportant variability on a small scale. Agricultural Water Management, 213, 1078-1083. doi: 10.1016/j.agwat.2018.07.017

Mota, W. N., Alves, J., Jr., Evangelista, A. W. P., \& Casaroli, D. (2018). SMUT-Sistema de baixo custo para aquisição de temperatura e umidade relativa do ar para manejo de irrigação. Revista Engenharia na Agricultura, 26(1), 89-99. doi: 10.13083/reveng. v26i1.897

Queiroz, T. M. de, Lima, S. C. R. V., Botrel, T. A., \& Frizzone, J.A. (2008). Coletor automático para ensaio de aspersores em laboratório (1) - desenvolvimento do modelo. Revista Brasileira de Agricultura Irrigada, 2(1), 24-28. doi: 10.7127/rbai.v2n100200

Ramadan, K. M., Oates, M. J., Molina-Martinez, J. M., \& Ruiz-Canales, A. (2018). Design and implementation of a low cost photovoltaic soil moisture monitoring station for irrigation scheduling with different frequency domain analysis probe structures. Computers and Electronics in Agriculture, 148, 148159. doi: 10.1016/j.compag.2017.12.038

Smajstrla, A. G., \& Zazueta, F. S. (1994). Evaporation loss during sprinkler irrigation. Gainesville: University of Florida Cooperative Extension Service, Institute of Food and Agriculture Sciences, EDIS. 
Surendran, U., Jayakumar, M., \& Marimuthu, S. (2016). Low cost drip irrigation: Impact on sugarcane yield, water and energy saving in semiarid tropical agro ecosystem in India. Science of The Total Environment, 573, 1430-1440. doi: 10.1016/j. scitotenv.2016.07.144

Tarjuelo, J. M., Ortega, J. F., Montero, J., \& De Juan, J. A. (2000). Modelling evaporation and drift losses in irrigation with medium size impact sprinklers under semi-arid conditions. Agricultural Water Management, 43(3), 263-84. doi: 10.1016/S03783774(99)00066-9
Wilcox, J. C., \& Swailes, G. E. (1947). Uniformity of water distribution by some undertree orchard sprinklers. Scientific Agriculture, 27(11), 565-583. DOI: $10.4141 /$ sa-1947-0067

Wu, D., Cui, Y., \& Luo, Y. (2019). Irrigation efficiency and water-saving potential considering reuse of return flow. Agricultural Water Management, 221, 519-527. doi: 10.1016/j.agwat.2019.05.021 
